\title{
Antibacterial Activity of Reduced Graphene Oxide
}

\author{
Riti Mann, ${ }^{1}$ Dimitrios Mitsidis, ${ }^{2}$ Zhirun Xie, ${ }^{2}$ Oliver McNeilly, ${ }^{1}$ Yun Hau Ng, $^{3}$ Rose Amal, ${ }^{2}$ \\ and Cindy Gunawan $\mathbb{D}^{1,2}$
}

${ }^{1}$ iThree Institute, University of Technology Sydney, Sydney, NSW 2007, Australia

${ }^{2}$ School of Chemical Engineering, UNSW Australia, Sydney, Australia

${ }^{3}$ School of Energy and Environment, City University of Hong Kong, Hong Kong

Correspondence should be addressed to Cindy Gunawan; cindy.gunawan@uts.edu.au

Received 8 March 2021; Revised 14 April 2021; Accepted 15 April 2021; Published 28 April 2021

Academic Editor: Liliana Cristina Soare

Copyright (c) 2021 Riti Mann et al. This is an open access article distributed under the Creative Commons Attribution License, which permits unrestricted use, distribution, and reproduction in any medium, provided the original work is properly cited.

The increasing biological use of graphene-based materials has prompted research inquiries on their effects on microorganisms. The work herein reported different types of microbiological activity of reduced graphene oxide (RGO). At relatively high concentrations (200 and $400 \mu \mathrm{g} / \mathrm{mL}$ ), RGO exhibited antibacterial activity on the model bacterium Escherichia coli, while at lower concentrations $(10$ and $50 \mu \mathrm{g} / \mathrm{mL}$ ), interestingly, no antibacterial effect was observed. Instead, an increase in the viable population after exposure at lower concentrations was observed, verified by colony counting and fluorescence microscopy. Further investigation ruled out the possibility of nutrient release from RGO being responsible for this growth-enhancing effect, whereby a comparable number of viable cells were found in the particle-free RGO leachate systems relative to the control. A before and after exposure X-ray photoelectron spectroscopy (XPS) analysis of the RGO detected less presence of C-C bond on the particle surface, suggesting the ability of the bacterium for the use of the carbon-based materials for growth. This potential RGO-cell interaction is further supported by the observed emergence of $\mathrm{C}-\mathrm{N}$ bond on the particle surface, the nitrogen moieties most likely of bacterial (cell envelope) origins. Although still an early evidence, such RGO-cell interactions could explain the viable cell increase observed at the lower concentration RGO systems. The present study highlights the concentration-dependent microbiological effects of RGO, clarifying the contradicting reports on the growth enhancing versus antibacterial effect of graphene-based materials. The knowledge is important not only for the antibacterial formulation of carbon-based materials but also when assessing their environmental impact.

\section{Introduction}

The indiscriminate use of antibiotics has led to the emergence of many drug-resistant bacteria, urging the need to explore for alternative antimicrobial agents. A range of nonconventional materials, such as metallic and metal oxide nanoparticles, and more recently, the carbon-based materials, such as nanotubes and graphene, have been studied [1-5]. When compared to other antimicrobials, graphene, a two-dimensional singleatom thick sheet of $\mathrm{sp}^{2}$ conjugated carbon atoms (arranged in hexagonal honeycomb lattices, the basal plane) $[2,6]$, is more cost effective to synthesize $[1,7,8]$. The antibacterial mechanisms of graphene have been indicated to mainly result from physical damages to bacterial membrane due to contact with its sharp edges [8-11]. The extensive use of toxic chemicals and high temperatures in the large scale production of graphene, however, has led to the development of graphenebased derivatives, such as graphene oxide (GO) and reduced graphene oxide (RGO) [12]. GO has epoxide groups on its basal plane and carboxylic groups on its edges (as well as hydroxyl groups in both basal plane and the edges) $[13,14]$, while RGO is produced by thermal annealing or chemical reduction of GO, leading to a reduction in oxygenated functional groups $[15,16]$.

There are many antibacterial studies on carbon-based materials, which have been the focus of various reviews $[1$, $2,17,18]$. These studies, however, reported contradicting observations. Studies have indeed observed the antibacterial effects of carbon-based materials, including the GO and RGO; yet, interestingly, more recent work have shown the possibility of these materials, for example, with GO, to promote cell proliferation, that is, as a potential carbon source 
for growth [19-22]. Our work herein focuses on the microbiological activity of RGO, of which studies are still relatively scarce, to clarify its antibacterial potential as opposed to the growth enhancing possibility.

Apart from antibacterial use, the scalable production of RGO has also been a major factor for its many other applications, such as in nanoelectronics, sensors, and photovoltaics [6]. This widespread use of RGO has prompted a growing concern for environmental impacts. The timely microbiological study will, therefore, not only provide insights into the optimum working concentration of RGO for the antibacterial effect but also, equally important, into the possible environmental impacts of RGO. Using the model bacterium Escherichia coli, the present work studied the viability of cells when exposed to a relatively wide concentration range of RGO, including treatments with the particle-free leachate systems. The latter is to validate the potential release of carbon source from RGO for cell growth. The work also used spectroscopy analysis to examine RGO-cell interactions, characterizing physical contact that could lead to the antibacterial versus growth enhancer effects in question.

\section{Experimental Section}

2.1. Synthesis of Reduced Graphene Oxide (RGO). The graphene oxide was prepared using the Hummers method, as illustrated in Figure 1. A weighed amount of $1 \mathrm{~g}$ graphite was first reacted with $500 \mathrm{mg}$ sodium nitrate $\left(\mathrm{NaNO}_{3}\right)$ in concentrated sulfuric acid $\left(\mathrm{H}_{2} \mathrm{SO}_{4}, 23 \mathrm{~mL}\right)$ at $\sim 0^{\circ} \mathrm{C}$ using ice bath, with $3 \mathrm{~g}$ potassium permanganate $\left(\mathrm{KMnO}_{4}\right)$ slowly added into the mixture, and dark green suspension was obtained. The partial oxidation and intercalation of graphite structure were initiated under the acidic oxidizing environment, leading to the introduction of oxygen-containing functional groups. The suspension was then removed from the ice bath and heated at $35-45^{\circ} \mathrm{C}$ for an hour to further the oxidizing and intercalating process. Subsequently, the suspension was diluted by first (gradually) adding $40 \mathrm{~mL}$ distilled water, followed by $10 \mathrm{~mL} 10 \%$ hydrogen peroxide $\left(\mathrm{H}_{2} \mathrm{O}_{2}\right)$ to remove excessive $\mathrm{KMnO}_{4}$. The as-prepared $\mathrm{GO}$ was then washed and filtered three times with the mixed solution of $5 \% \mathrm{H}_{2} \mathrm{SO}_{4}$ and $5 \% \mathrm{H}_{2} \mathrm{O}_{2}$. The remaining solid was dried in a vacuum desiccator at ambient temperature and grounded into fine powder.

RGO was prepared by the chemical reduction of GO using a solution-based approach. $100 \mathrm{mg} \mathrm{GO}$ was suspended in $\sim 200 \mathrm{~mL}$ distilled water, sonicated, and reduced by adding the reducing agent $\mathrm{NaBH}_{4}(\sim 0.4 \mathrm{~g})$ to the slowly stirred mixture in a glycerol bath, followed by heating at $80^{\circ} \mathrm{C}$ for $4 \mathrm{~h}$. The so-obtained RGO flakes were filtered, washed three times with distilled water, and dried at $60^{\circ} \mathrm{C}$.

2.2. Solid State Characterization of RGO. X-ray diffraction (XRD) analysis was performed on an MPD Xpert Multipurpose X-ray Diffraction System operating at $45 \mathrm{kV}$ and $40 \mathrm{~mA}$ using $\mathrm{Cu} \mathrm{K} \alpha$ radiation $(\lambda=1.54 \AA)$.

For transmission electron microscopy (TEM), a dilute suspension of RGO was first prepared by adding a small amount of the particles into ethanol solution. This suspension was dropped onto the copper grid, which was then allowed to dry. TEM analysis was performed on a PhillipsCM200 electron microscope. The RGO sample was suspended in aqueous solution at $0.1 \mathrm{mg} / \mathrm{mL}$ with $\mathrm{pH}$ adjusted to 7.0 for the zeta-potential ( $\zeta$-potential) measurement (Zeta PALS, Brookhaven).

$\mathrm{X}$-ray photoelectron spectroscopy (XPS) was employed to study changes in the elemental surface composition of RGO following the bacterial exposure. To isolate the particles, the RGO-cell suspensions were first centrifuged at 5,000 rpm, 5 min to pellet down the cells. The supernatant containing the RGO particles was further centrifuged at $12,000 \mathrm{rpm}$, $20 \mathrm{~min}$ to settle the particles. The particle pellets were dried using a vacuum desiccator for XPS analysis. XPS analysis was performed in a vacuum chamber $\left(<2 \times 10^{-9} \mathrm{mbar}\right)$ on an ESCALab220i-XL probe (VG Scientific) with monochromated AlK $\alpha$ radiation ( $\mathrm{h} v=1486.6 \mathrm{eV}$ ). The XPS spectra of the particles were compared before and after cell exposure.

2.3. RGO-Agar Assay. An overnight culture was prepared by inoculating a single colony of $E$. coli $\mathrm{HB}_{101} \mathrm{~K}-12$ strain (Biorad) into $10 \mathrm{~mL}$ Luria Bertani (LB) medium, then incubated at $30^{\circ} \mathrm{C}, 200 \mathrm{rpm}$ for $16-17 \mathrm{~h}$. For assay plates, $150 \mathrm{~mL}$ LB agar was prepared in deionised (Milli-Q) water, autoclaved $\left(121^{\circ} \mathrm{C}, 15 \mathrm{~min}\right)$ and cooled in a $50^{\circ} \mathrm{C}$ water bath for $30 \mathrm{~min}$. A measured volume of $100 \mu \mathrm{L}$ of the overnight culture was added to the agar, swirled to mix, and $25 \mathrm{~mL}$ was poured into each petriplate. Plates were allowed to set properly, bagged (double contained), inverted, and stored at $4^{\circ} \mathrm{C}$ for use the next day.

Filter paper disks of $3 \mathrm{~cm}$ (whatmann) were autoclaved $\left(121^{\circ} \mathrm{C}, 15 \mathrm{~min}\right)$, cooled to room temperature, soaked in respective RGO suspensions $(0,10,50,100,200$, and $400 \mu \mathrm{g} / \mathrm{mL}$ ), and placed on the agar surface. Plates were incubated at $37^{\circ} \mathrm{C}$ for $6 \mathrm{~h}$. Filter papers were picked, and plates were inverted and incubated overnight at $37^{\circ} \mathrm{C}$. Next day, plates were examined for appearance of surface colonies on the area where the filter papers were placed.

2.4. RGO-Cell Exposure and Cell Viability Assessment. The optical density (OD) of the overnight culture, as prepared above, was measured using a spectrophotometer at $600 \mathrm{~nm}$. A measured volume of the overnight culture was transferred into fresh $25 \mathrm{~mL} \mathrm{LB}$ (to give OD of 0.05 ), then grown to early exponential phase by further incubating at $37^{\circ} \mathrm{C}$, $250 \mathrm{rpm}$ for $1 \mathrm{~h}$. The cells were then harvested and repeatedly washed in sterile saline (phosphate buffered saline) to remove the culture medium. The cell pellets were resuspended in $25 \mathrm{~mL}$ sterile saline to make the stock E. coli for cell viability experiments.

E. coli was exposed to $10,50,100,200$, and $400 \mu \mathrm{g} / \mathrm{mL}$ RGO for $3 \mathrm{~h}$ (at $37^{\circ} \mathrm{C}, 250 \mathrm{rpm}$ ), initiated by inoculation of the cell stock into RGO suspensions (sonicated) in sterile saline $\left(\sim 10^{7} \mathrm{cfu} / \mathrm{mL}\right.$ cell concentration). A cell-only system (in saline) served as control. Following the exposure, the cell viability was determined using the colony counting method. Briefly, $1 \mathrm{~mL}$ samples from the RGO-cell and cell-only systems were serially diluted, with $100 \mu \mathrm{L}$ of the final dilution $\left(10^{4}\right.$ dilution factor) spread-plated in duplicates on LB agar $\left(37^{\circ} \mathrm{C}\right.$ incubation). The colonies (as colony forming unit, 


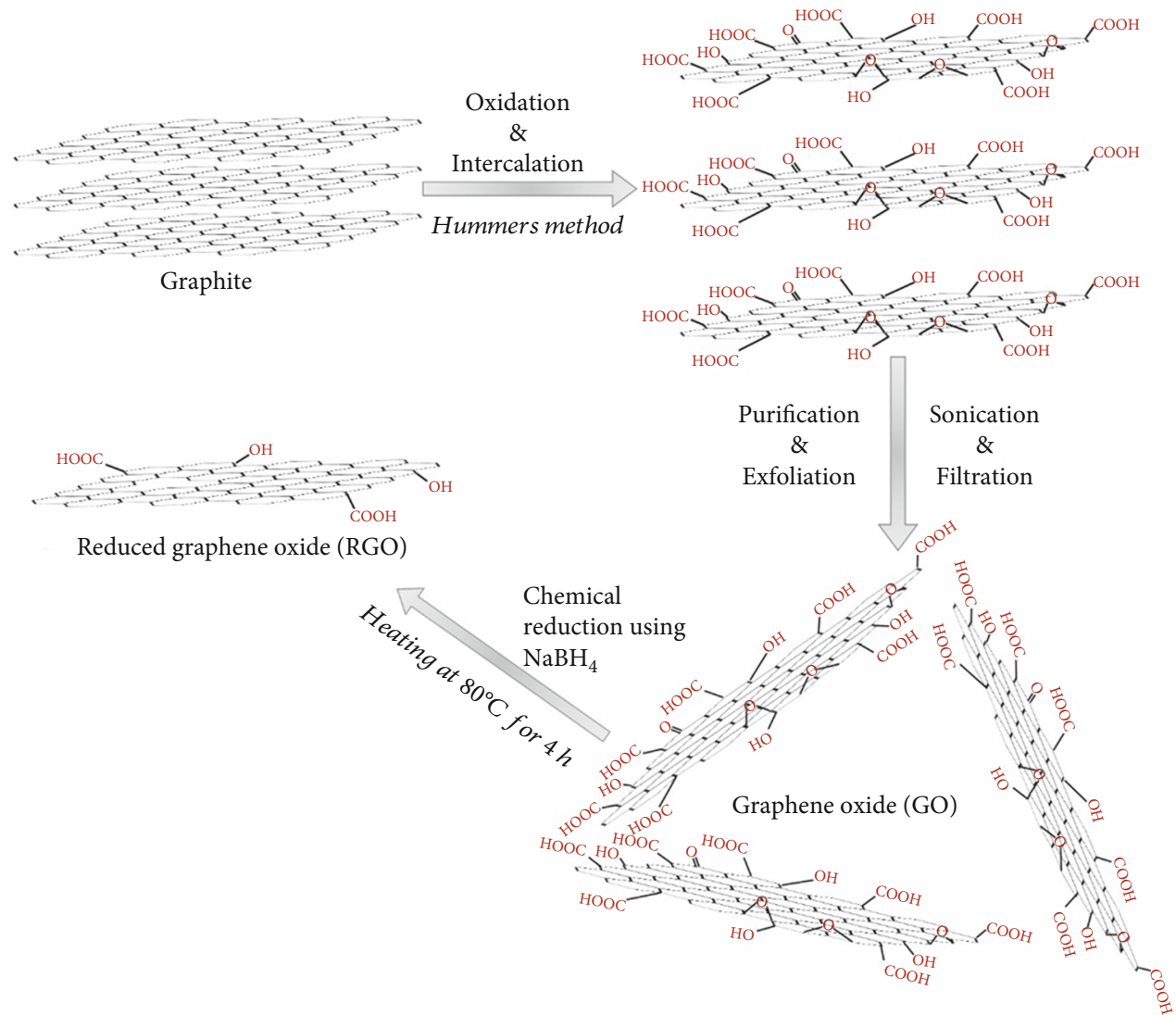

FIGURE 1: Synthesis of reduced graphene oxide (RGO) by the chemical reduction of graphene oxide (GO, synthesized by the Hummers method) using the reducing agent $\mathrm{NaBH}_{4}$.

$\mathrm{CFU} / \mathrm{mL}$ ) were counted the next day, and the percentages of cell viability were calculated relative to the $0 \mathrm{~h}$ time point for each system.

The cell viability was also assessed using fluorescence staining, whereby $1 \mathrm{~mL}$ of the exposure and cell-only samples was stained with the nucleic acid-sensitive $5 \mu \mathrm{M}$ Syto 9 (Thermofisher Scientific) and $30 \mu \mathrm{M}$ propidium iodide (Thermofisher Scientific) dyes for $15 \mathrm{~min}$ at room temperature under dark condition. Syto 9 dye is cell permeable (therefore stain all cells), while propidium iodide will only enter cells with damaged cytoplasmic membrane, indicative of dead cells. The stained samples were then washed with sterile saline to remove unreacted dyes. The cells were visualized using Olympus BX61 fluorescence microscope (460-490 nm excitation filter setting).

2.5. Cell Exposure to RGO Leachate. To prepare the leachate, RGO suspension in saline $(10,50,100,200$, and $400 \mu \mathrm{g} / \mathrm{mL})$ was centrifuged at $12,000 \mathrm{rpm}$ for $20 \mathrm{~min}$ for particle removal. Growth curves in the presence of leachates of different RGO concentrations were set up in 96-well plates (Corning, Australia). A total of $150 \mu \mathrm{L}$ was prepared with $15 \mu \mathrm{L}$ of the overnight culture diluted to an optical density of 0.5 , $100 \mu \mathrm{L}$ of the RGO leachate $(1.5 \times$ concentrated), and $35 \mu \mathrm{L}$ of LB broth. All wells on the outer edge of the plate were filled with sterile Milli-Q water to prevent evaporation during the incubation process. Plate was incubated at $37^{\circ} \mathrm{C}, 250 \mathrm{rpm}$ in a Tecan Spark $10 \mathrm{M}$ plate reader (Tecan) with the pro- gram set to measure the optical density (OD, at $600 \mathrm{~nm}$ ) every $30 \mathrm{~min}$. The $\mathrm{OD}$ readings for $10 \mathrm{~h}$ were plotted against time, and the doubling times of the E. coli cells in different leachate systems were calculated. Growth studies were performed with three biological replicates (with independent E. coli cultures and leachate preparations), each with two technical replicates.

For cell viability experiments, E. coli was exposed to the RGO leachate following the methodology described above for the RGO-cell exposure. Briefly, E. coli stock, prepared as explained above, was inoculated into the supernatant (RGO leachate) $\left(\sim 10^{7} \mathrm{cfu} / \mathrm{mL}\right.$ cell concentration $)$ and incubated for $3 \mathrm{~h}$ (at $37^{\circ} \mathrm{C}, 250 \mathrm{rpm}$ ) for cell viability studies, a cellonly system (in saline) served as control. Following the incubation, the cell viability was determined using the colony counting method, as earlier described.

2.6. Total Carbon (TC) and Total Organic Carbon (TOC) Measurement. RGO-leachate samples were sent to the Envirolab (Sydney) for carbon analysis. The total carbon and organic carbon were determined using the combustion method, in accordance to the APHA (American Public Health Association) 5310B protocol.

\section{Results and Discussion}

3.1. Solid State Characterization of RGO. RGO, as outlined in the experimental section, was synthesized by the chemical 


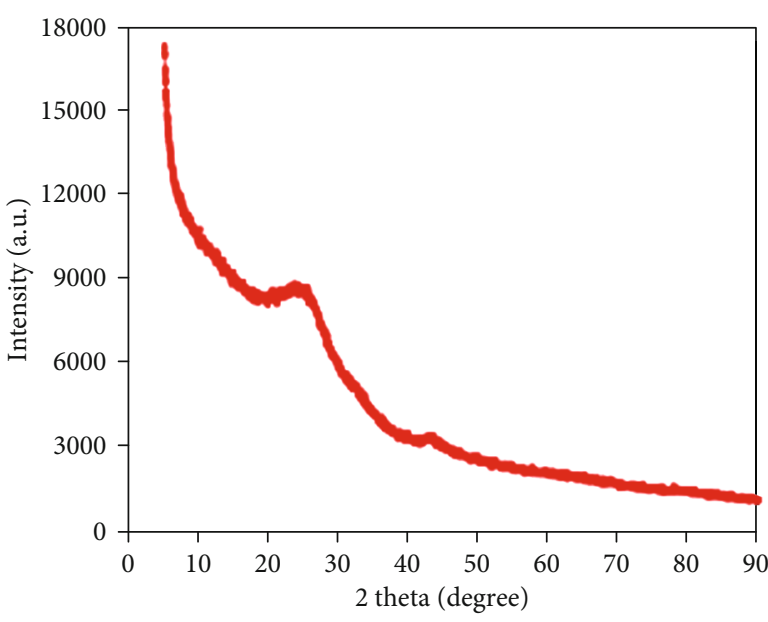

(a)

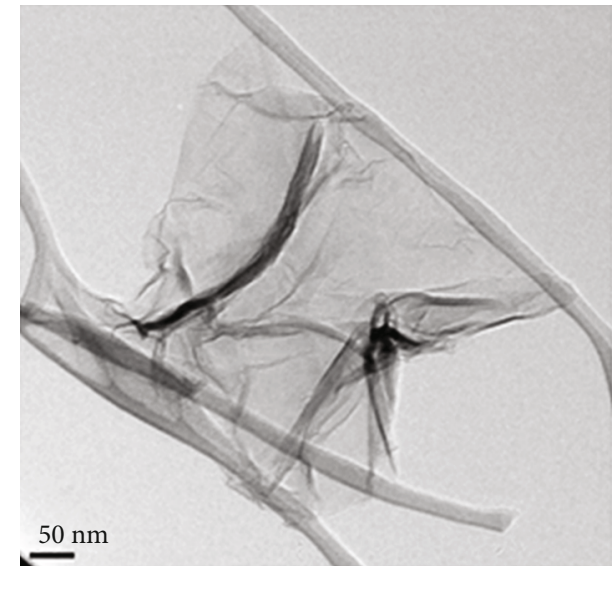

(b)

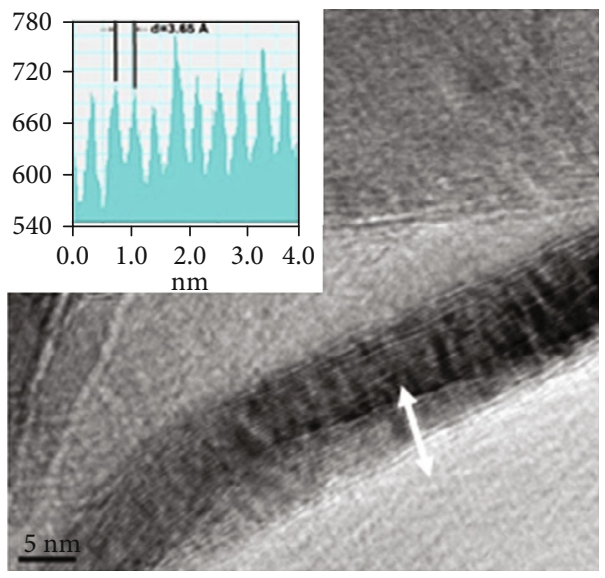

(c)

FIGURE 2: Solid state characterization of the reduced graphene oxide (RGO) particles. (a) X-ray diffraction patterns. (b, c) TEM images of the RGO sheets at different magnifications.

reduction of GO. The acquired $\mathrm{RGO}$ was characterized by $\mathrm{X}$ ray diffraction (XRD) and transmission electron microscopy (TEM). As shown in Figure 2(a), noticeable XRD diffraction peak was observed at $24.3^{\circ}$, which is indexed to the (002) planes of the graphitic structure with $d$-spacing of $3.66 \AA$ calculated based on Bragg's equation. This broad peak indicates the amorphous nature of RGO. The minor peak at $43.1^{\circ}$ is interrelated to the diffraction of (100) planes.

TEM images were taken for the RGO particles embedded on a copper grid to further investigate their structure and provide insights into the morphology of these particles. As shown in Figure 2(b), the RGO samples have a sheet-like structure with 1-2 $\mu \mathrm{m}$ dimensions. The cross-section of the stacks of RGO sheets with the layered graphitic structure is shown in Figure 2(c). A stack of multiple layers was used to quantify the average interlayer distance, and it was calculated to be around $3.65 \AA$ (Figure 2(c) inset), comparable to the $d$-spacing obtained from the XRD spectra. The XRD pattern and TEM images confirmed that the RGO was successfully exfoliated, and an orderly layered structure was obtained.
3.2. Microbiological Effects of RGO: Growth Enhancer and Antibacterial Agent. Herein, the microbiological activity of 10 to $400 \mu \mathrm{g} / \mathrm{mL}$ reduced graphene oxide (RGO) was investigated on the model bacterium $E$. coli. The relatively wide concentration range is to cover both "extremes" of the microbiological effects in question, that is, as growth enhancer or as antibacterial agent. Firstly, an agar surface colony assay was performed, whereby LB agar containing E. coli cells was exposed to filter papers previously soaked in increasing concentrations of RGO particle preparations $\left(6 \mathrm{~h}, 37^{\circ} \mathrm{C}\right)$, followed by overnight incubation of the agar at $37^{\circ} \mathrm{C}$. The emergence of surface colonies was examined on the agar where the filter papers had been placed. As shown in Figure 3(a), no surface colonies were observed in the salineonly $(0 \mu \mathrm{g} / \mathrm{mL}), 100$, and $400 \mu \mathrm{g} / \mathrm{mL}$ systems, while colonies emerged on the agar exposed in the 10,50 , and $200 \mu \mathrm{g} / \mathrm{mL}$ systems, as indicated by the red arrows and circles. These results suggest the possibility of growth enhancing effect of $\mathrm{RGO}$, at certain concentration range. To further test the hypothesis, the E. coli liquid system was exposed to increasing RGO concentrations with a minimal presence of $\mathrm{LB}$ 


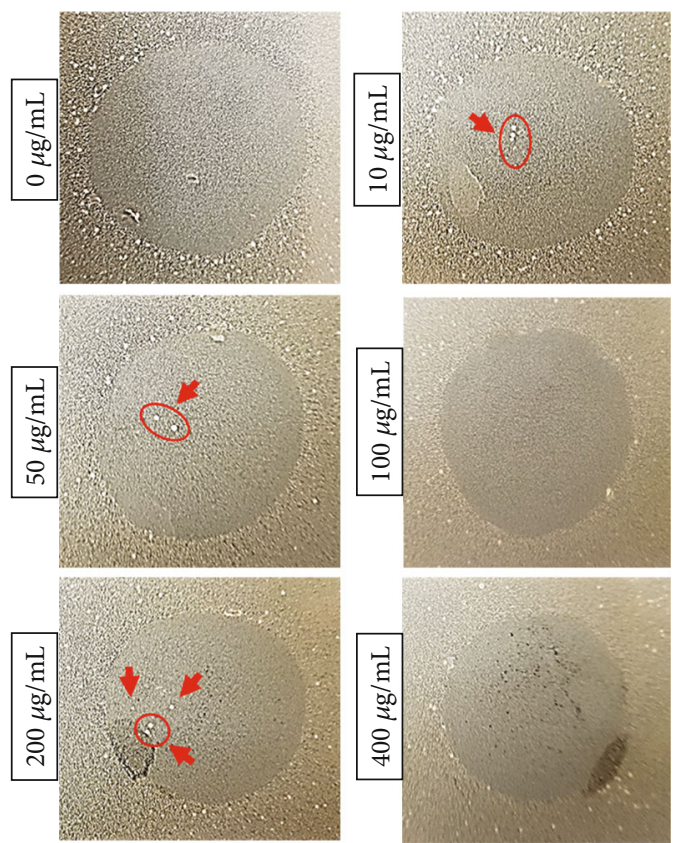

(a)

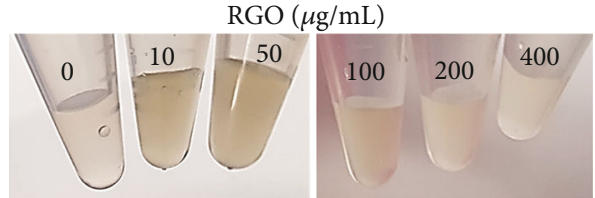

(b)

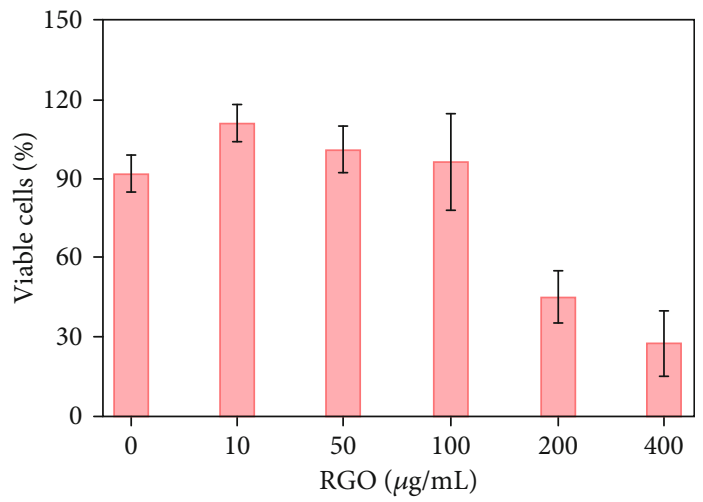

(c)

FIGURE 3: Cell viability assessment of the model bacterium E. coli upon exposure to increasing concentration of RGO particles. (a) Surface colony studies using the agar assay. LB agar containing E. coli was exposed to sterile filter papers $(3 \mathrm{~cm}$ diameter) previously soaked in increasing concentrations of RGO particle suspension $(0,10,50,100,200$, and $400 \mu \mathrm{g} / \mathrm{mL})$ for $6 \mathrm{~h}$, and the agar was then incubated overnight at $37^{\circ} \mathrm{C}$. (b) Turbidity of E. coli (in saline and minimal presence of culture medium) exposed to increasing concentrations of RGO particles, after $16 \mathrm{~h}$ incubation at $37^{\circ} \mathrm{C}, 250 \mathrm{rpm}$. (c) Cell viability assessment using the agar colony counting method, after incubating the cells with RGO saline suspensions for $3 \mathrm{~h}$ at $37^{\circ} \mathrm{C} / 250 \mathrm{rpm}$. For each $\mathrm{RGO}$ concentration, the data represents the percentages of viable cells at the end of the exposure relative to those of at time zero. The data is the average of three biologically independent experiments (different bacterial inocula and particle preparations), each with three technical replicates $(n=9)$. The error bars represent the standard error of mean (SEM).

broth ( $20 \%$ total culture volume). The systems after overnight incubation at $37^{\circ} \mathrm{C}$ are shown in Figure 3(b). Relative to the visibly clear saline-only $(0 \mu \mathrm{g} / \mathrm{mL})$ system, turbidity was observed in the 10 and $50 \mu \mathrm{g} / \mathrm{mL}$ systems; at $100 \mu \mathrm{g} / \mathrm{mL}$, only a slight turbidity was seen; and essentially clear systems at 200 and $400 \mu \mathrm{g} / \mathrm{mL}$, again, indicating a potential growthenhancing effects of RGO, at the lower concentration range of 10 and $50 \mu \mathrm{g} / \mathrm{mL}$.

The above experiments were carried out in the presence of LB medium, involving a relatively long growth incubation step, both of which could have influenced the effects of RGO on the model bacterium. In our next experiment, any presence of nutrients in the systems was removed to ensure an RGO only-induced effect, as well as reducing the particle exposure time to $3 \mathrm{~h}$, to account for any swift microbiological effects of RGO. Bacterial cultures were first grown to their early exponential phase, repeatedly washed in saline to remove nutrient residues from the culture medium, then were exposed to the increasing concentrations of RGO nanosheets in saline $\left(37^{\circ} \mathrm{C}, 3 \mathrm{~h}\right)$. Following the exposure, the number of viable cells (as colony forming units (CFUs) grown on agar) was expressed as percentages relative to those at the start of the exposure for the respective RGO concentration. As shown in Figure 3(c), no adverse effect on the viable cell population at 10 and $50 \mu \mathrm{g} / \mathrm{mL}$ RGO concentrations was observed. Instead, an up to $10 \%$ more viable cells were detected at these concentrations after the $3 \mathrm{~h}$ exposure (relative to the initial viable cell population in the respective system). The control system was in fact associated with $\sim 10 \%$ less viable cells after $3 \mathrm{~h}$ (relative to the initial viable cell population in the system). The results indicate the cell proliferation effect at the lower concentration 10 and $50 \mu \mathrm{g} / \mathrm{mL}$ RGO exposures. Increasing the concentration to $200 \mu \mathrm{g} / \mathrm{mL}$, RGO saw a $~ 50 \%$ less viable cells after $3 \mathrm{~h}$, and only about a third of the cells were viable in the $400 \mu \mathrm{g} / \mathrm{mL}$ RGO system. The results indicate the antibacterial effect at the higher RGO concentration exposures.

It is noteworthy to point out that there have been contradicting reports in regard to the microbiological activity of graphene-based materials, including the RGO, and this has been summarized for the latter in Table 1. Previous studies have covered a wide range of RGO concentrations, from $25 \mu \mathrm{g} / \mathrm{mL}$ to the extremely high $3000 \mu \mathrm{g} / \mathrm{mL}$, tested on different model bacteria, using various approaches, including cell viability, growth analysis, and DNA damages and ROS generation. RGO has shown antibacterial activity, with studies reporting varying extent of effects at different RGO concentrations on Gram-positive and Gram-negative bacteria 
TABLE 1: Literature summary of RGO effects on different bacterial species.

\begin{tabular}{|c|c|c|c|}
\hline Bacteria & Evaluation method & $\begin{array}{c}\text { RGO concentrations } \\
(\mu \mathrm{g} / \mathrm{mL})\end{array}$ & Effects \\
\hline E. coli $[10]$ & Cell viability & 40 & Growth inhibition \\
\hline $\begin{array}{l}\text { Pseudomonas } \\
\text { aeruginosa [24] }\end{array}$ & $\begin{array}{l}\text { Growth profile } \\
\text { Cell viability } \\
\text { ROS generation } \\
\text { DNA } \\
\text { fragmentation }\end{array}$ & $\begin{array}{c}25,50,75,100,125,150 \\
175,200\end{array}$ & Growth inhibition \\
\hline $\begin{array}{l}\text { E. coli } \\
\text { Staphylococcus } \\
\text { aureus [9] }\end{array}$ & $\begin{array}{c}\text { Cell viability } \\
\text { RNA concentration }\end{array}$ & $\begin{array}{c}\text { Growth monitored on } \\
\text { RGO surface }\end{array}$ & Growth inhibition \\
\hline E. coli $[23]$ & $\begin{array}{l}\text { Cell viability } \\
\text { ROS generation } \\
\text { DNA } \\
\text { fragmentation }\end{array}$ & $25,50,75,100,125,150$ & Growth inhibition \\
\hline E. coli $[8]$ & $\begin{array}{l}\text { Cell viability } \\
\text { ATP assay }\end{array}$ & 85 & Growth inhibition \\
\hline $\begin{array}{l}\text { S. aureus } \\
P . \text { aeruginosa [25] }\end{array}$ & $\begin{array}{l}\text { Growth curve } \\
\text { Nucleic acid } \\
\text { leakage } \\
\text { ROS generation } \\
\text { SEM images }\end{array}$ & $1000,2000,3000$ & Growth inhibition \\
\hline E. coli $[12]$ & $\begin{array}{c}\text { Cell viability } \\
\text { ROS generation }\end{array}$ & 40 & Growth inhibition \\
\hline $\begin{array}{l}\text { E. coli } \\
\text { S. aureus [26] }\end{array}$ & $\begin{array}{l}\text { Growth curve } \\
\quad \text { Biofilm } \\
\text { quantification } \\
\text { ROS generation }\end{array}$ & $\begin{array}{c}0.5,5,10,50,100,250 \\
500\end{array}$ & Growth and biofilm inhibition \\
\hline $\begin{array}{l}\text { Soil bacterial } \\
\text { community [27] }\end{array}$ & $\begin{array}{l}\text { Bacterial 16S rRNA } \\
\text { gene } \\
\text { Analysis }\end{array}$ & $\begin{array}{l}0.001,1,1000 \mu \mathrm{g} \\
\quad \text { Per kg soil }\end{array}$ & $\begin{array}{l}\text { Altered bacterial community composition in comparison to the no- } \\
\text { treatment control } \\
\text { Alpha diversity, depicting the number of taxonomic groups in a } \\
\text { microbial community, was not altered }\end{array}$ \\
\hline E. coli $[28]$ & Cell viability & $1000 \mu \mathrm{g} / \mathrm{mL}$ & No growth inhibition \\
\hline $\begin{array}{l}\text { Bacillus subtilis } \\
P . \text { aeruginosa [29] }\end{array}$ & $\begin{array}{l}\text { RGO integrated in } \\
\text { solid agar }\end{array}$ & $0.01-0.08 \%$ & Growth inhibition \\
\hline $\begin{array}{l}\text { B. subtilis } \\
\text { E. coli }[30] \\
\end{array}$ & Agar well diffusion & $100,400,800 \mu \mathrm{g} / \mathrm{mL}$ & Growth inhibition \\
\hline $\begin{array}{l}\text { E. coli } \\
\text { S. aureus [31] }\end{array}$ & Agar well diffusion & $10000 \mu \mathrm{g} /$ well & Growth inhibition \\
\hline
\end{tabular}

species, with their distinct cell envelope structures $[10,12,23$, 24]. In relation to our results, using E. coli as the model bacterium, Gurunathan et al. also observed an antibacterial effect of RGO, with loss of cell viability when increasing the RGO concentration from 100 to $400 \mu \mathrm{g} / \mathrm{mL}[23,24]$, which also in agreement with other studies. However, in contrast to our results, previous studies, for example, Liu et al., did not observe any increase in cell viability at the lower RGO exposures, in their case at 40 and $50 \mu \mathrm{g} / \mathrm{mL}$ [10]. This effect, as described earlier, has been seen with graphene oxide, but not with RGO. At this stage, it can be deduced from the present work agar viable colony counting and growth turbidity data that RGO at relatively low concentrations seemed to "promote" bacterial growth, while the antibacterial effect occurs at higher concentration, or in other words, the micro- biological activity of RGO is concentration-dependent. The next studies were carried out to confirm the phenomena and obtain insights into the underlying mechanisms.

3.3. Studies with RGO Leachate and Bacteria-RGO Interactions. To first confirm the concentration-dependent microbiological activity, the RGO-exposed bacterial samples were subjected to fluorescent viability staining. Upon exposure to $10 \mu \mathrm{g} / \mathrm{mL}$ and even $50 \mu \mathrm{g} / \mathrm{mL}$ RGO (in saline, $37^{\circ} \mathrm{C}$, $3 \mathrm{~h}$ ), essentially, no dead cells were observed (propidium iodide staining), and more cells were indeed present in the systems (Syto9 staining) when compared to the initial cell population (Figures 4(a)-4(f)), therefore, consistent with the agar studies. Also consistent with the agar studies, increasing the RGO concentration to 200 and $400 \mu \mathrm{g} / \mathrm{mL}$ 


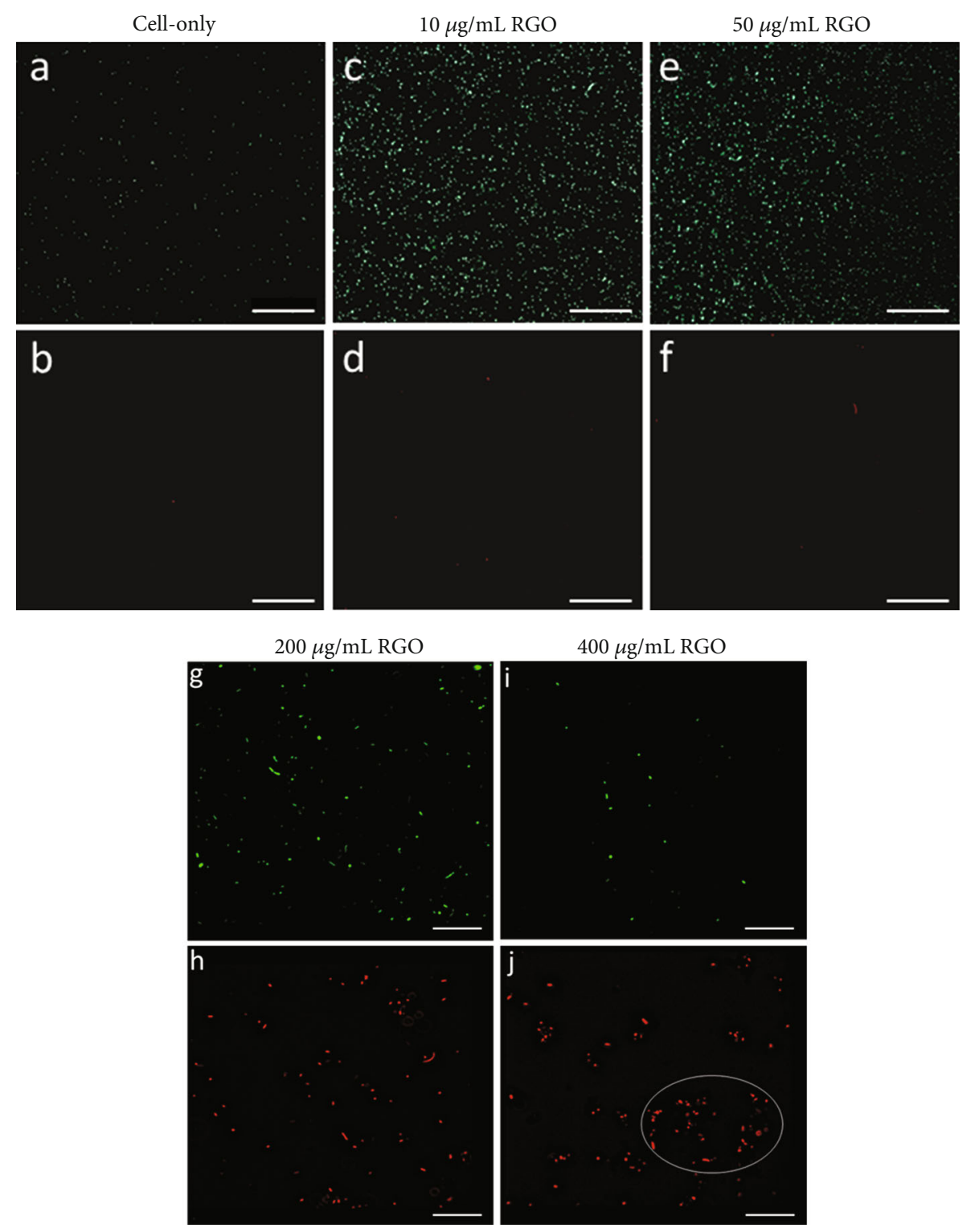

FIGURE 4: Fluorescent staining to assess cell viability in E. coli RGO systems ( $\left.3 \mathrm{~h}, 37^{\circ} \mathrm{C}\right)$. The upper panel shows total cell population (both viable and dead cells) stained in green (Syto 9 staining), and the lower panel shows dead cells stained in red (propidium iodide staining) (scale bar $=50 \mu \mathrm{m}$ ). Note that for the 10 and $50 \mu \mathrm{g} / \mathrm{mL}$ RGO systems, the fluorescence staining seemed to reveal more live cells (relative to the cell-only control after exposure) when compared to those given by the agar colony counting method. This indicates presence of live but nonproliferating cells in the RGO systems, with the colony counting method only detecting live proliferating cells. It is also apparent that there were less cells present in the 200 and $400 \mu \mathrm{g} / \mathrm{mL}$ RGO systems (relative to the control after exposure), which could be due to physical piercing of the cells by RGO, with the noticeable presence of cellular debris (white circle).

saw substantial cell killing with the fluorescent staining (Figurse 4(g)-4(j)). Among several possible mechanisms, studies have mainly attributed the antibacterial action of RGO to cell ruptures due to the physical piercing of cell envelope when in contact with particles' sharp edges [8-11, 25]. The apparent stimulation of bacterial growth following exposure to the lower concentrations of RGO is an interesting observation. It is hypothesized that there could be release of carbon nutrients from the particles to stimulate the bacterial growth. Alternatively, research inquiries have also hypothesized that bacteria are capable of "direct" use of RGO as potential carbon source for proliferation [32].
To test the first hypothesis, the RGO particles were preincubated at the tested 10 to $400 \mu \mathrm{g} / \mathrm{mL}$ concentrations in saline for 2 days, followed by removal of the particles. The resulting particle-free "leachate" solution was then studied for the potential of the model bacterium E. coli to proliferate in the solution. Firstly, a growth profile was examined in the presence of leachate of increasing RGO concentrations, to also include a saline-only $(0 \mu \mathrm{g} / \mathrm{mL})$ control. The growth profiles and the cell doubling time (the time taken for the model bacterium to double its population) calculated for each treatment are presented in Figure 5(a). Relative to the saline-only control, the presence of RGO leachate did not affect the 

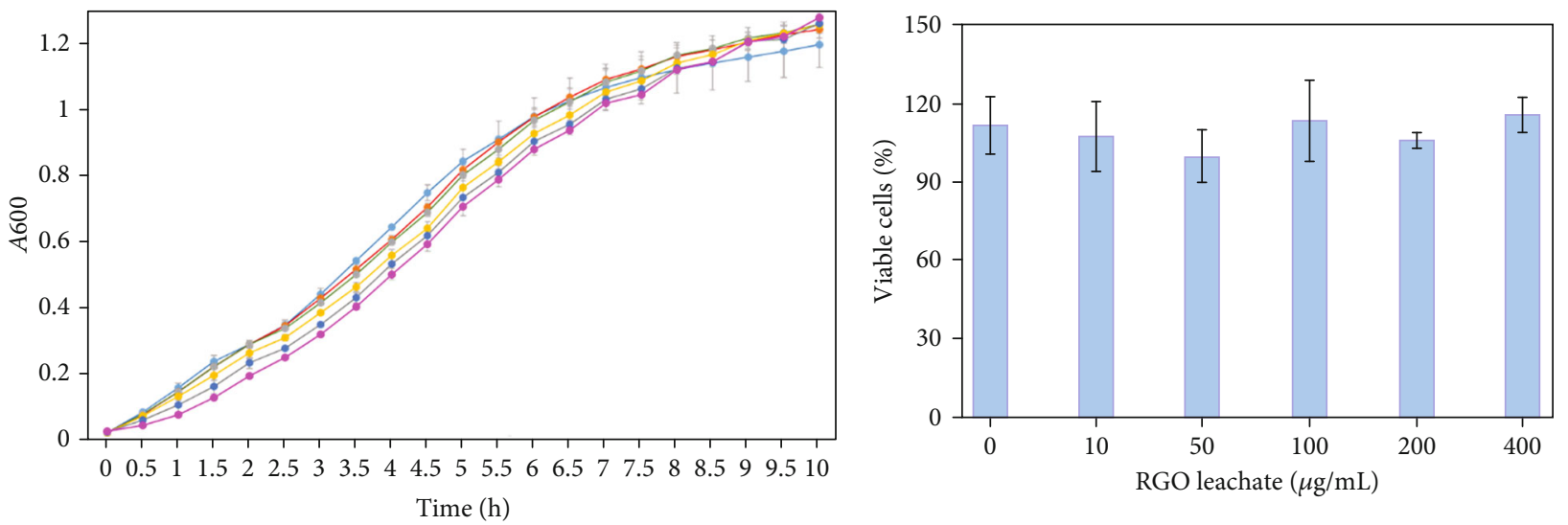

Generation time $(\mathrm{h})$

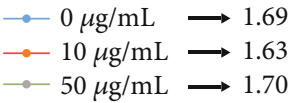

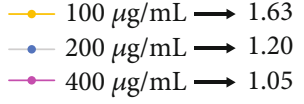

(a) (b)

Figure 5: Cell viability assessment of E. coli upon exposure to (particle-free) RGO leachate. (a) Growth analysis of $E$. coli when exposed to leachate of increasing RGO concentrations over a time period of $10 \mathrm{~h}$. The respective doubling times are mentioned in the inset. The data represents the average of three biological replicates (different bacterial inocula and leachate preparations), each with two technical replicates $(n=6)$. The error bars represent the standard deviation (SD). (b) Cell viability assessment $\left(3 \mathrm{~h}, 37^{\circ} \mathrm{C}\right)$ using the agar colony counting method. For each leachate system, the data represents the percentages of viable cells at the end of the exposure relative to those at time zero. The data is the average of three biologically independent experiments (different bacterial inocula and leachate preparations), each with three technical replicates $(n=9)$. The error bars represent the standard error of mean (SEM).
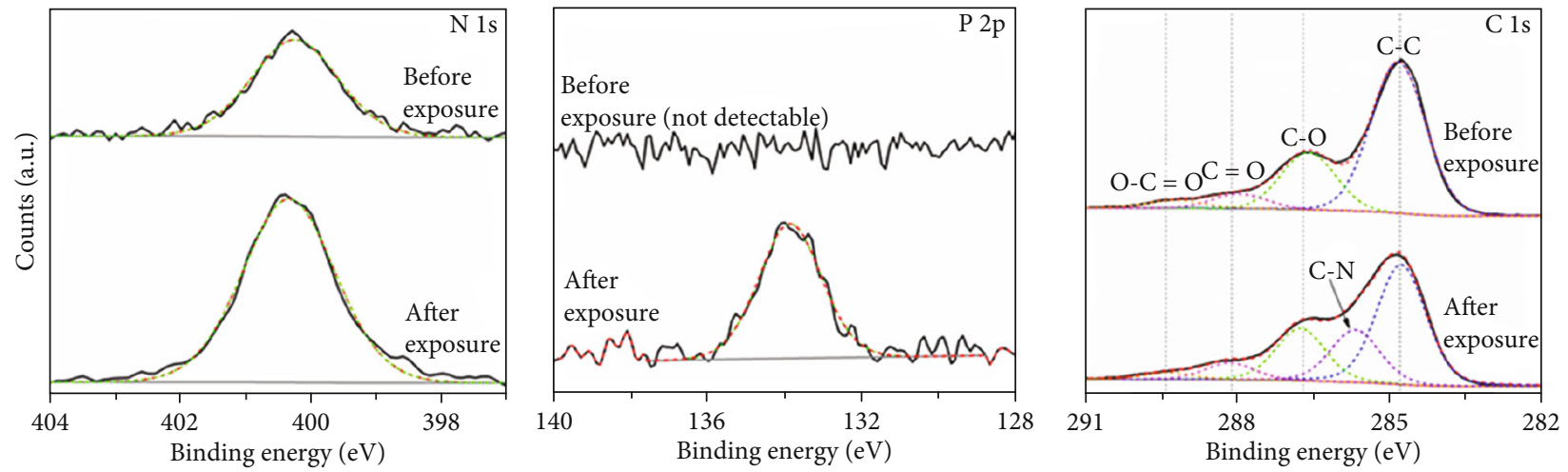

FIGURE 6: XPS analysis of the RGO particles prior to and after incubation with bacteria. Note that the occurrence of the N1 peak on the "before exposure" RGO was most likely due to contamination during particle synthesis.

doubling time of E. coli at all concentrations, except at 200 and $400 \mu \mathrm{g} / \mathrm{mL}$, whereby a slight decrease in doubling time was observed. However, as the growth curve studies are based on the optical density (OD) measurements, which account for the total cell population, the readings could also include the presence of dead cells. Next, an agar colony counting was performed to obtain the concentration of viable cells in the RGO leachate systems. Following the $3 \mathrm{~h}$ exposure, as shown in Figure 5(b), the number of viable cells (as CFUs grown on agar) in the 10 to $400 \mu \mathrm{g} / \mathrm{mL}$ RGO leachate systems was similar to those at the start of the exposure for the respective system, and these are comparable to the cell-only (in saline) control. For the lower concentration RGO exposures $(10$ and $50 \mu \mathrm{g} / \mathrm{mL}$ ), these findings indicate less likely contri- bution from the leachate for the observed increase in the number of viable cells after RGO particle exposures. In fact, only negligible presence of carbon $(<5 \mu \mathrm{g} / \mathrm{mL})$ was detected in the leachate at all tested RGO concentrations (analyzed before bacterial exposure, data not shown), indicating that there was hardly any substrate that can be utilized for cell growth. The data therefore excludes the possibility of nutrient release from the particles that is thought to promote the bacterium proliferation.

Next, to get insights into the second hypothesis, changes on the particle surface were characterized by assessing the elemental composition before and after the bacterial exposure (analysed at the lower concentration RGO exposures). Using the X-ray photoelectron spectroscopy (XPS), changes 
in C1s spectra were observed, as shown in Figure 6. There was a decrease in the presence of C-C bond $(284.8 \mathrm{eV})$ on the RGO surface after the exposure, which could suggest for the use of RGO as carbon source by the bacterium. Studies have indeed reported the ability of various bacterial species to degrade graphene and its derivatives $[20,33]$. The Gramnegative bacteria Pseudomonas sp. for instance can serve as electron acceptor and oxidizes graphite, GO, and RGO, among which RGO was found to be the most extensively oxidized, degrading into smaller carbon moieties [33]. Enzymatic degradation of graphene-derived materials has also been reported, for example, with the activity of peroxidases that catalyze the oxidation of GO $[34,35]$. Further, studies have indicated the growth-enhancing effects of carbonbased materials on cells. Exposure of plant cells to carbon nanotubes, for example, saw an enhanced proliferation rate, with the phenomena being correlated to the detected upregulation of genes that are involved in cell division and extension [19]. At this stage, however, it still remains unclear as with the exact processes of the indicated C-C bond cleaving in the present work. E. coli has been known to synthesize enzymes that can cleave $\mathrm{C}-\mathrm{C}$ bond, for example, via the meta-cleavage pathway; yet, it is unknown if these enzymes are secreted by the bacterium [36]. The potential RGO-cell interaction in the current work is consistent with the detected emergence of C-N bond $(286 \mathrm{eV})$ on the RGO surface after bacterial exposure, which was most likely associated with the cleaving of $\mathrm{C}-\mathrm{C}$ bond. The nitrogen is thought of bacterial origins. Gram-negative bacteria like E. coli have an amphiphilic molecule, the so-called lipopolysaccharide or LPS anchoring on their outer membrane, and being exposed to the external environment. A likely source for the nitrogen in the $\mathrm{C}-\mathrm{N}$ bond is the known presence of glucosamine phosphate moieties in LPS [4]. The nitrogen could also come from the outer membrane phospholipids. Phosphatidylethanolamine, for example, as one of the major phospholipids, has phosphate-amine moieties that are exposed to the external environment [4]. Indeed, a higher presence of phosphorus was detected (P2p spectra, single peak at $134 \mathrm{eV}$, as well as nitrogen, N1s spectra, single peak at $\sim 400 \mathrm{eV}$ ) on the RGO surface after exposure, although the phosphorus could also originate from the saline medium (phosphate buffered saline). There was no observed changes in the presence of the carbonyl $\mathrm{C}(\mathrm{C}=\mathrm{O}, 288.2 \mathrm{eV})$ and carboxylate $\mathrm{C}(\mathrm{O}-\mathrm{C}=$ $\mathrm{O}, 289.5 \mathrm{eV}$ ) on the RGO surface. The spectral peaks of these functional groups, which are present at the edge of the structure, were similar before and after bacterial exposure. This excludes the possible bacterial "attack" on the edge C-C bond (those that connect the $\mathrm{O}-\mathrm{C}=\mathrm{O}$ to the base plane). There was also no change in the presence of the hydroxyl/epoxy $\mathrm{C}(\mathrm{C}-\mathrm{O}$, $286.6 \mathrm{eV}$ ) on the RGO surface. In agreement, the oxygen content of the RGO was comparable at $\sim 30 \%$, before and after bacterial exposure.

\section{Conclusions}

Addressing the contradicting reports on the "growth enhancing" versus "growth inhibiting" effects of graphene-based materials, the present work describes the concentration- dependent microbiological activity of reduced graphene oxide (RGO) on a model bacterium. RGO exhibited cellkilling activities on $E$. coli at relatively high particle concentrations (200 and $400 \mu \mathrm{g} / \mathrm{mL}$ ), while cell proliferation was observed at lower particle concentrations (10 and $50 \mu \mathrm{g} / \mathrm{mL}$ ), being validated by both agar colony counting and fluorescence viability staining methods. For the indicative growth enhancing effect, an elemental analysis (XPS) found a decreased presence of $\mathrm{C}-\mathrm{C}$ bond on the RGO surface after bacterial exposure, suggesting the use of RGO as carbon source by the bacterium, with cell viability assessments in (particle-free) RGO leachate systems that exclude the possibility of nutrient release from RGO. The potential RGO-cell direct interaction was further supported by the detected emergence of $\mathrm{C}-\mathrm{N}$ bond on the particle surface after the exposure, and the nitrogen moieties were most likely of bacterial (cell envelope) origins. The potential process of $\mathrm{C}-\mathrm{C}$ bond cleavage by the bacterial cells, however, still remains largely unclear and warrants further investigation. Taken together, the studies herein present important data on the effective dosage range of RGO-based antibacterial formulations, which is particularly important in this era of increasing antimicrobial resistance, with bacterial pathogens already developing adaptation to antibiotics, as well as to the alternative antimicrobials, the latter including metal-based nanoparticles. The work also provides an insight into the environmental impact of RGO, with research inquiries already reporting the release of graphene-based materials into the environment [37]. The release of RGO into the environment could promote unintended growth, shifting the composition and metabolic balance of natural microbial communities, which could in turn affect important ecological processes.

\section{Data Availability}

The data used to support the findings of this study are included within the article.

\section{Conflicts of Interest}

There are no conflicts of interest to declare.

\section{Acknowledgments}

This work is supported by the Australian Research Council Discovery Project (DP 180100474).

\section{References}

[1] P. Kumar, P. Huo, R. Zhang, and B. Liu, "Antibacterial properties of chitosan," Nanomaterials, vol. 9, no. 737, 2017.

[2] S. M. Notley, R. J. Crawford, and E. P. Ivanova, "Novel ionic liquid-type Gemini surfactants: Synthesis, surface property and antimicrobial activity," In Advances in Graphene Science, vol. 395, pp. 116-124, 2012.

[3] M. B. Faiz, R. Amal, C. P. Marquis et al., "Nanosilver and the microbiological activity of the particulate solids versus the leached soluble silver," Nanotoxicology, vol. 12, no. 3, pp. 263273, 2018. 
[4] C. Gunawan, M. B. Faiz, R. Mann et al., "Nanosilver targets the bacterial cell envelope: the link with generation of reactive oxygen radicals," ACS Applied Materials \& Interfaces, vol. 12, no. 5, pp. 5557-5568, 2020.

[5] C. Gunawan, W. Y. Teoh, C. P. Marquis, and R. Amal, "Cytotoxic origin of copper (II) oxide nanoparticles: comparative studies with micron-sized particles, leachate, and metal salts," ACS Nano, vol. 5, no. 9, pp. 7214-7225, 2011.

[6] A. K. Geim and K. S. Novoselov, "The rise of graphene," Nature Materials, vol. 6, no. 3, pp. 183-191, 2007.

[7] A. Geim and K. Graphene, "Graphene: Status and prospects," Science, vol. 324, no. 5934, pp. 1530-1534, 2009.

[8] W. Hu, C. Peng, W. Luo et al., "Graphene-based antibacterial paper," ACS Nano, vol. 4, no. 7, pp. 4317-4323, 2010.

[9] O. Akhavan and E. Ghaderi, "Toxicity of graphene and graphene oxide nanowalls against bacteria," ACS Nano, vol. 4, no. 10, pp. 5731-5736, 2010.

[10] S. Liu, T. H. Zeng, M. Hofmann et al., "Antibacterial activity of graphite, graphite oxide, graphene oxide, and reduced graphene oxide: membrane and oxidative stress," ACS Nano, vol. 5, no. 9, pp. 6971-6980, 2011.

[11] O. Akhavan, E. Ghaderi, and A. Esfandiar, "Wrapping bacteria by graphene Nanosheets for isolation from environment, reactivation by sonication, and inactivation by near-infrared irradiation," The Journal of Physical Chemistry. B, vol. 115, no. 19, pp. 6279-6288, 2011.

[12] P. Choudhary and S. K. Das, "Bio-reduced graphene oxide as a nanoscale antimicrobial coating for medical devices," ACS Omega, vol. 4, no. 1, pp. 387-397, 2019.

[13] O. C. Compton and S. T. Nguyen, "Graphene oxide, highly reduced graphene oxide, and graphene: versatile building blocks for carbon-based materials," Small, vol. 6, no. 6, pp. 711-723, 2010.

[14] S. Park and R. S. Ruoff, "Erratum: Chemical methods for the production of graphenes," Nature Nanotechnology, vol. 5, no. 4 , p. $309,2010$.

[15] S. Pei and H. M. Cheng, "The reduction of graphene oxide," Carbon N. Y., vol. 50, no. 9, pp. 3210-3228, 2012.

[16] J.-H. Yun, Y. H. Ng, R. J. Wong, and R. Amal, "Reduced graphene oxide : control of water miscibility, conductivity, and defects by photocatalysis," ChemCatChem, vol. 5, no. 10, pp. 3060-3067, 2013.

[17] A. M. Jastrzębska, P. Kurtycz, and A. R. Olszyna, "Recent advances in graphene family materials toxicity investigations," Journal of Nanoparticle Research, vol. 14, no. 12, pp. 13201321, 2012.

[18] A. Nel, T. Xia, L. Mädler, and N. Li, “Toxic potential of materials at the nanolevel," Science, vol. 311, no. 5761, pp. 622-627, 2006.

[19] M. V. Khodakovskaya, K. De Silva, A. S. Biris, E. Dervishi, and H. Villagarcia, "Carbon nanotubes induce growth enhancement of tobacco cells," ACS Nano, vol. 6, no. 3, pp. 21282135, 2012.

[20] M. Chen, X. Qin, and G. Zeng, "Biodegradation of carbon nanotubes, graphene, and their derivatives," Trends in Biotechnology, vol. 35, no. 9, pp. 836-846, 2017.

[21] M. Chen, G. Zeng, P. Xu, C. Lai, and L. Tang, "How do enzymes 'meet' nanoparticles and nanomaterials?," Trends in Biochemical Sciences, vol. 42, no. 11, pp. 914-930, 2017.

[22] G. Lalwani, W. Xing, and B. Sitharaman, "Enzymatic degradation of oxidized and reduced Graphene Nanoribbons by lignin peroxidase," Journal of Materials Chemistry B, vol. 2, no. 37, pp. 6354-6362, 2014.

[23] S. Gurunathan, J. W. Han, A. A. Dayem et al., "Antibacterial activity of dithiothreitol reduced graphene oxide," Journal of Industrial and Engineering Chemistry, vol. 19, no. 4, pp. 1280-1288, 2013.

[24] S. Gurunathan, J. W. Han, A. A. Dayem, V. Eppakayala, and J.-H. Kim, "Oxidative stress-mediated antibacterial activity of graphene oxide and reduced graphene oxide in pseudomonas aeruginosa," International Journal of Nanomedicine, vol. 7, pp. 5901-5914, 2012.

[25] I. Sengupta, P. Bhattacharya, M. Talukdar, S. Neogi, S. K. Pal, and S. Chakraborty, "Bactericidal effect of graphene oxide and reduced graphene oxide: influence of shape of bacteria," Colloid Interface Sci. Commun., vol. 28, pp. 60-68, 2019.

[26] Z. Guo, C. Xie, P. Zhang et al., "Toxicity and transformation of graphene oxide and reduced graphene oxide in bacteria biofilm," Sci. Total Environ., vol. 580, pp. 1300-1308, 2017.

[27] C. Forstner, T. G. Orton, P. Wang, P. M. Kopittke, and P. G. Dennis, "Effects of carbon nanotubes and derivatives of graphene oxide on soil bacterial diversity," Sci. Total Environ., vol. 682, pp. 356-363, 2019.

[28] A. Kromka, J. Jira, P. Stenclova et al., "Bacterial response to nanodiamonds and graphene oxide sheets," Physica Status Solidi, vol. 253, no. 12, pp. 2481-2485, 2016.

[29] V. R. S. S. Mokkapati, S. Pandit, J. Kim et al., "Bacterial Response to Graphene Oxide and Reduced Graphene Oxide Integrated in Agar Plates," Royal Society Open Science, vol. 5, no. 11, 2018.

[30] M. N. Rani, S. Ananda, and D. Rangappa, "Preparation of reduced Graphene oxide and its antibacterial properties," Materials Today: Proceedings, vol. 4, no. 11, pp. 1230012305, 2017.

[31] A. Thakur, S. Kumar, M. Sharma, and V. S. Rangra, "Optical, electrical and antimicrobial studies of chemically synthesized graphite oxide and reduced graphene oxide," Advanced Materials Letters, vol. 7, no. 12, pp. 1029-1034, 2016.

[32] S. Kang, Y. Zhu, M. Chen et al., "Can microbes feed on environmental carbon nanomaterials?," Nano Today, vol. 25, pp. 10-12, 2019.

[33] L. Liu, C. Zhu, M. Fan et al., "Oxidation and degradation of graphitic materials by naphthalene-degrading bacteria," Nanoscale, vol. 7, no. 32, pp. 13619-13628, 2015.

[34] G. P. Kotchey, B. L. Allen, H. Vedala et al., "The enzymatic oxidation of Graphene oxide," ACS Nano, vol. 5, no. 3, pp. 2098-2108, 2011.

[35] R. Kurapati, J. Russier, M. A. Squillaci et al., "Dispersibilitydependent biodegradation of graphene oxide by myeloperoxidase," Small, vol. 11, no. 32, pp. 3985-3994, 2015.

[36] E. Diaz, A. Ferrandez, M. A. Prieto, and J. L. Garcia, "Biodegradation of Aromatic Compounds byEscherichia coli," Microbiology and Molecular Biology Reviews, vol. 65, no. 4, pp. 523-569, 2001.

[37] A. K. Dasmahapatra, T. P. S. Dasari, and P. B. Tchounwou, "Graphene-based nanomaterials toxicity in fish," Reviews of Environmental Contamination and Toxicology, vol. 247, pp. 1-58, 2019. 